\title{
Expanding the provenance toolkit beyond detrital zircon dating: a test case from the Merrimack River
}

\author{
Richard Gaschnig \\ University of Massachusetts Lowell
}




\section{Limitations of detrital zircon geochronology in provenance analysis}

- Strong bias towards felsic magmatism (especially Zr-rich plutons)

- Little info on metamorphic history

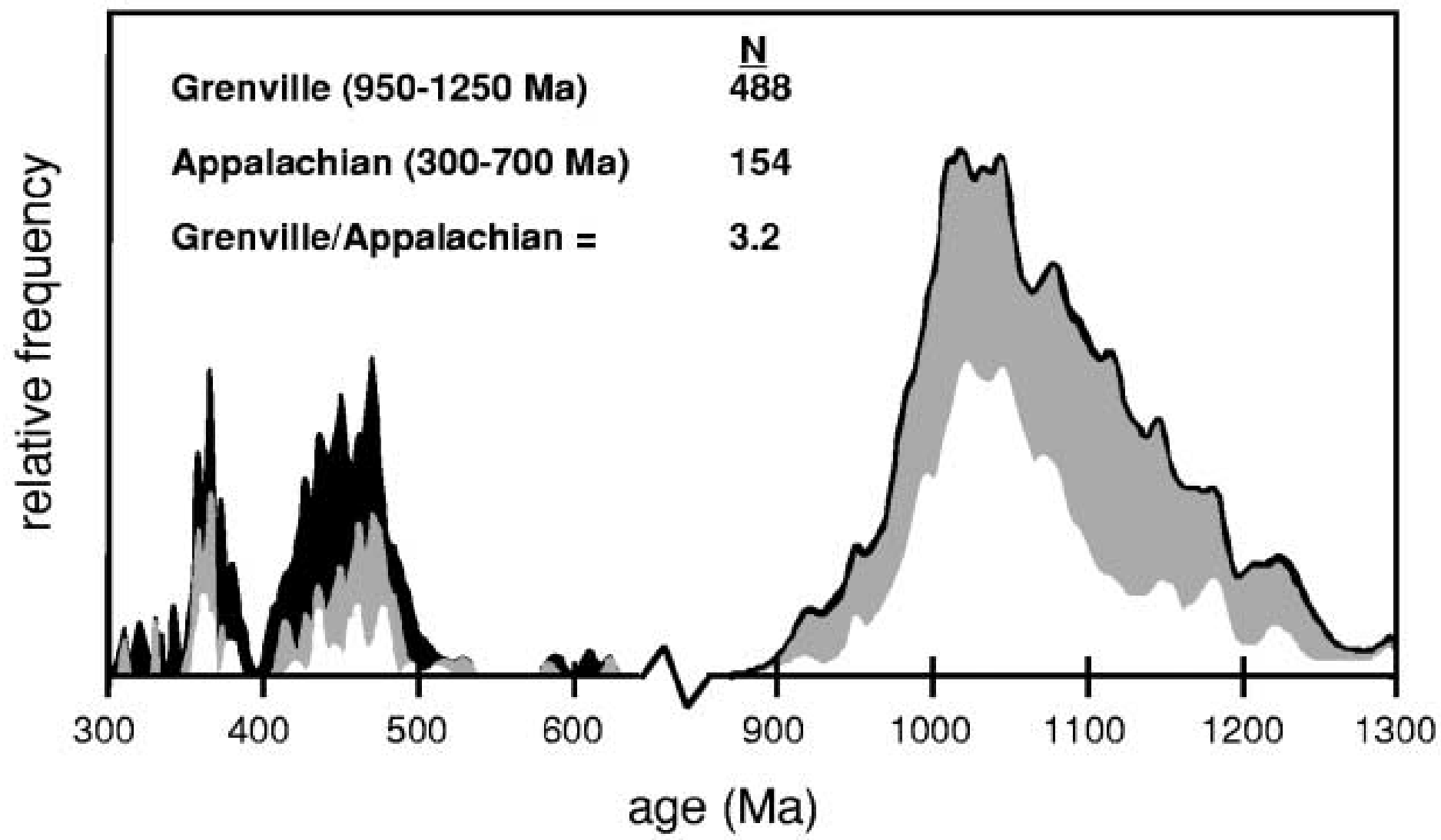

From Eriksson et al (2003)

- Alien geologists sampling detrital zircons from the major Appalachian rivers might assume that Appalachians formed mostly between 1.0 and $1.1 \mathrm{Ga}$ and would completely miss Alleghanian orogeny 


\section{Limitations of detrital zircon geochronology in provenance analysis}

- Zircon age spectra are often non-unique

- As LaMaskin (2012) noted, coeval Cordilleran sediments have very similar age populations from California to Alaska

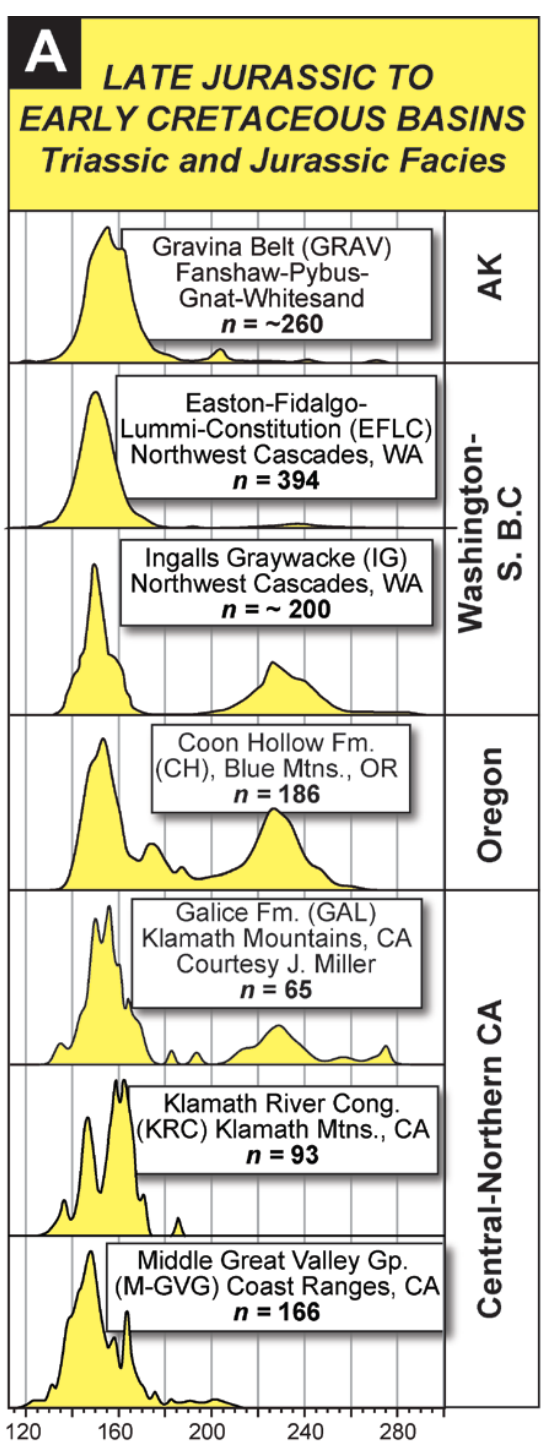

Age (Ma)

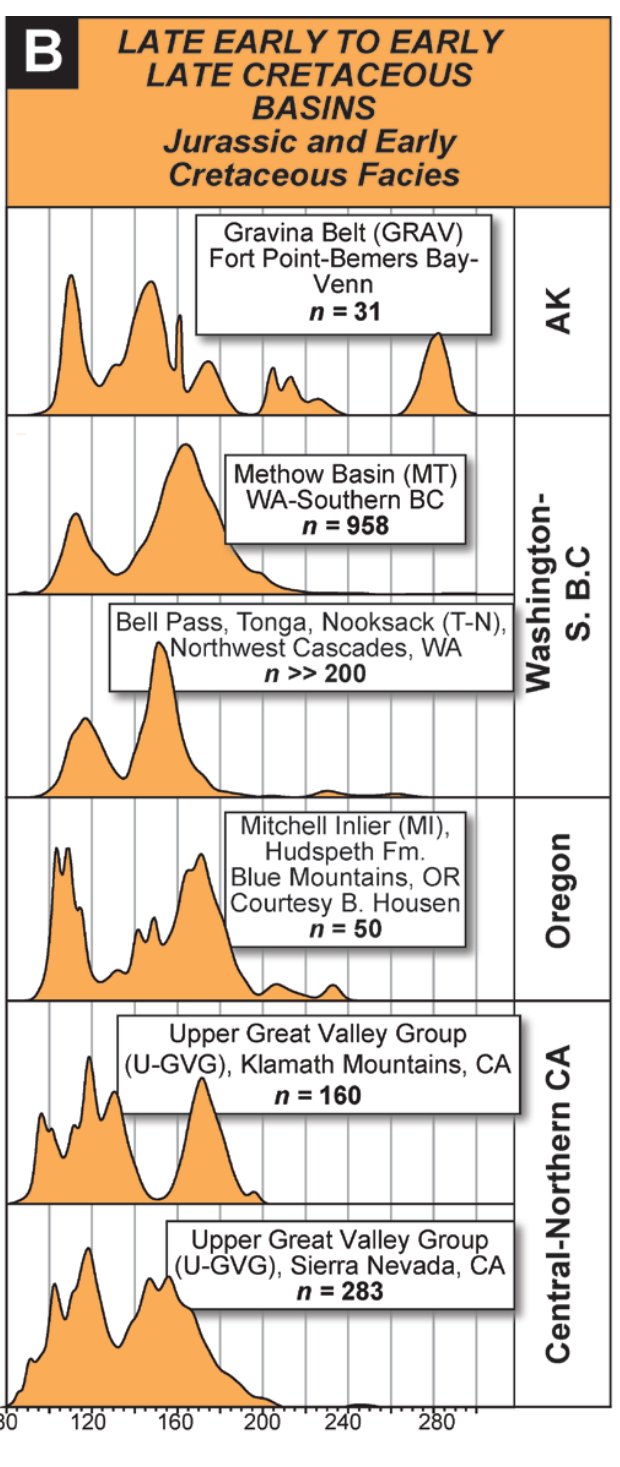

Age (Ma) 


\section{Limitations of detrital zircon geochronology in provenance analysis}

- Survivability means that it is often recycled from older sediments

- We cannot say much about tectonic setting of these zircon source rocks from $\mathrm{U}-\mathrm{Pb}$ ages alone 


\section{This talk - an example of a multi- mineral approach applied to local river sediment}

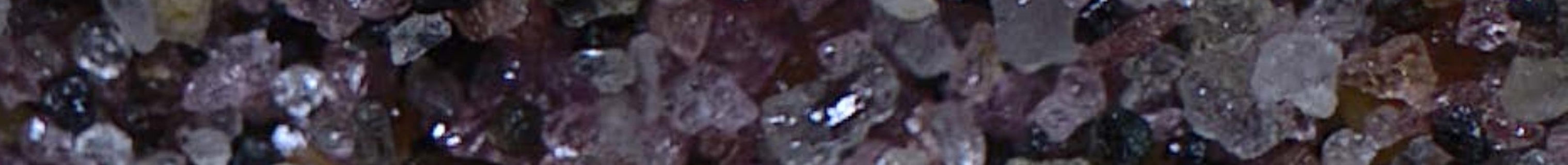




\section{The sample}

- Garnet-rich sand from mouth of Merrimack

\section{River}

- River flows out of

Mesozoic White Mtns province through various Paleozoic pluton and metasedimentary belts

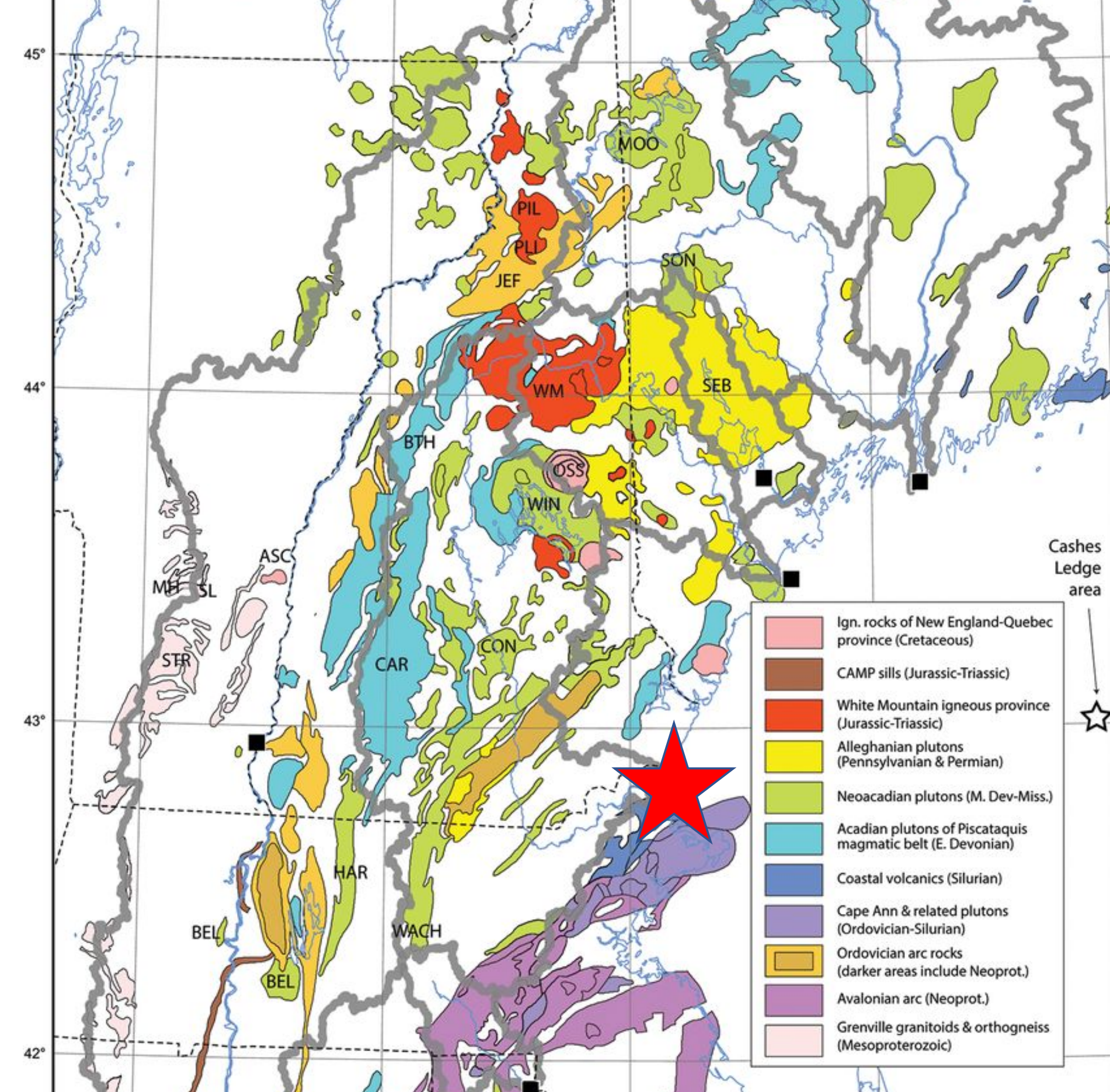




\section{Proxies used here}

-Zircon (old reliable)

- U-Pb ages - track major episodes of intermediate to felsic magmatism

- Trace elements - may distinguish source rock type (e.g., Belousova et al., 2002; Grimes et al., 2015) 


\section{Proxies used here}

- Monazite

- U-Th-Pb ages - records metamorphism in variety of rock types; occasional igneous phase

- Trace elements - may distinguish source rock type (e.g., Itano et al., 2016) 


\section{Proxies used here}

- Rutile

- U-Pb ages - records metamorphism in variety of rock types

- If exhumation is slow, ages will reflect cooling rather than peak metamorphism

- Trace elements - may distinguish source rock type (e.g., Triebold et al., 2007)

- $\mathrm{Zr}$ concentration is temperature dependent (Zack et al., 2004) 


\section{Proxies used here}

- Titanite

- $\mathrm{U}-\mathrm{Pb}$ ages - Common in many igneous rock types; also forms in several metamorphic environments

- Trace elements - may distinguish source rock type (e.g., Aleinikoff et al., 2002) 
- All analyses conducted at UMass Lowell with CETAC LSX213 G2+ laser and Agilent 7900 Q-ICP-MS

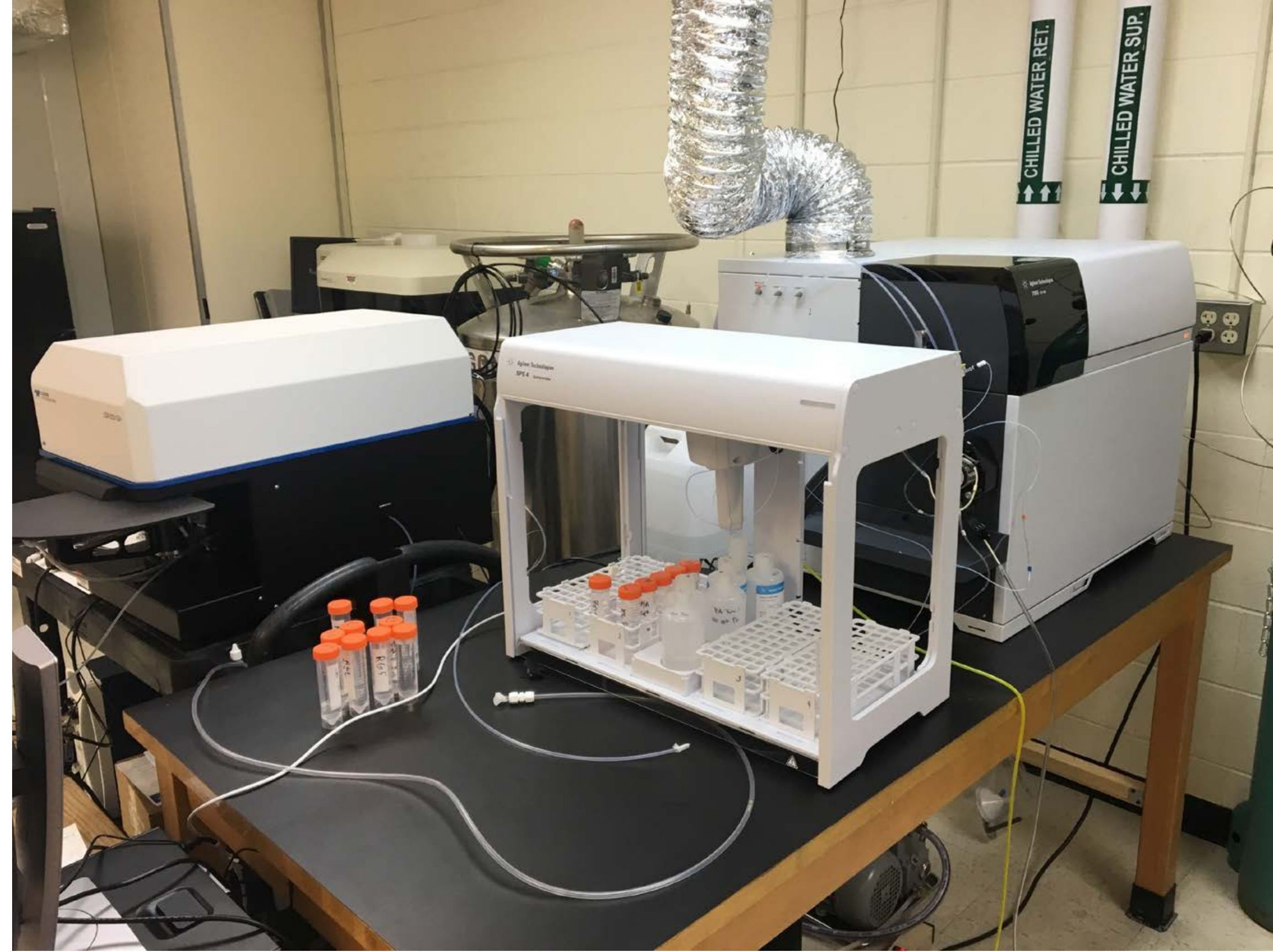




\section{Zircon age results}

- Major peak $400 \mathrm{Ma}$ and lesser peaks at 200 and 120

- Identical to Bradley et al (2015)

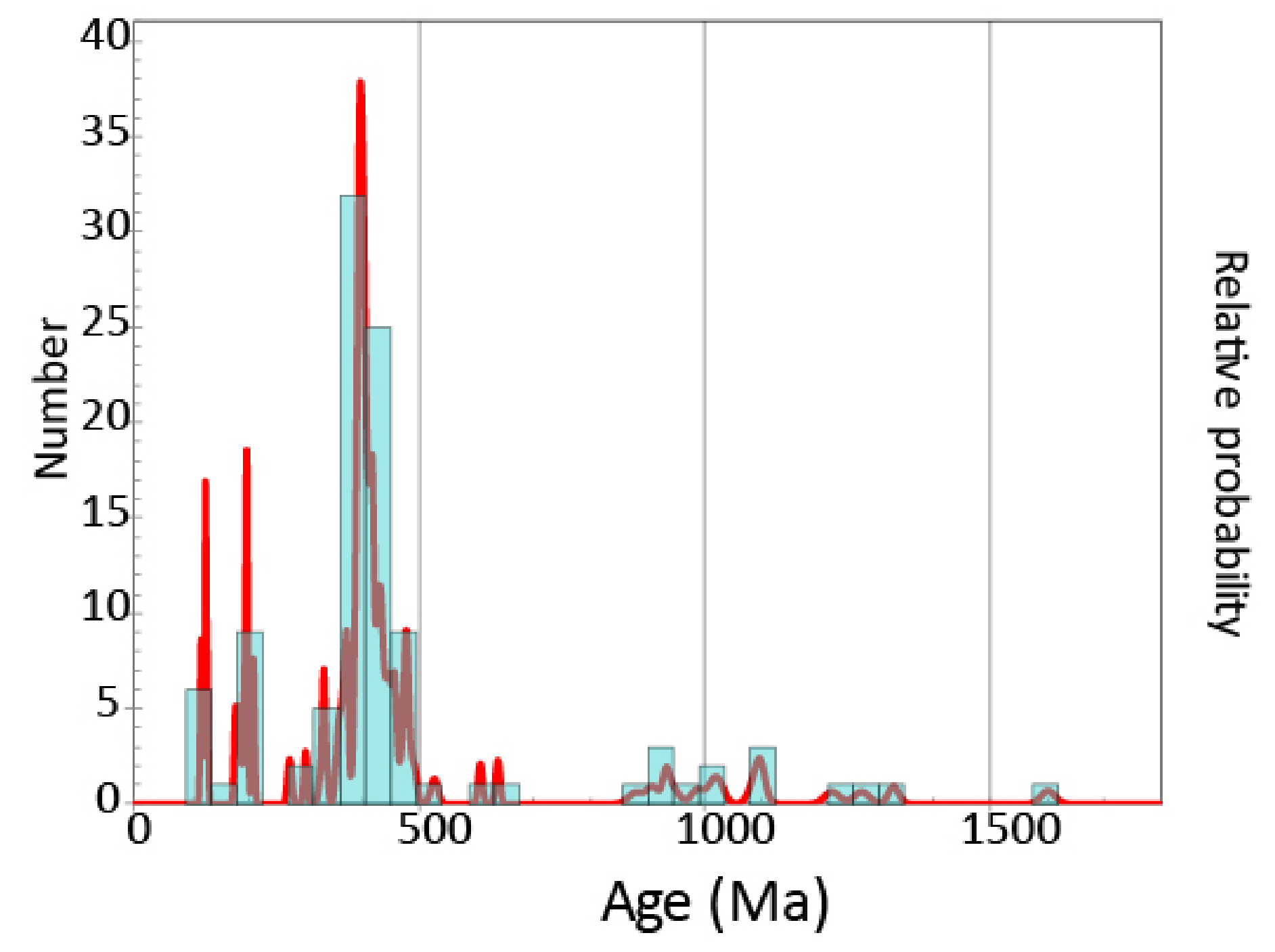




\section{Zircon age results}

- Major peak $400 \mathrm{Ma}$ and lesser peaks at 200 and 120

- Identical to Bradley et al (2015)

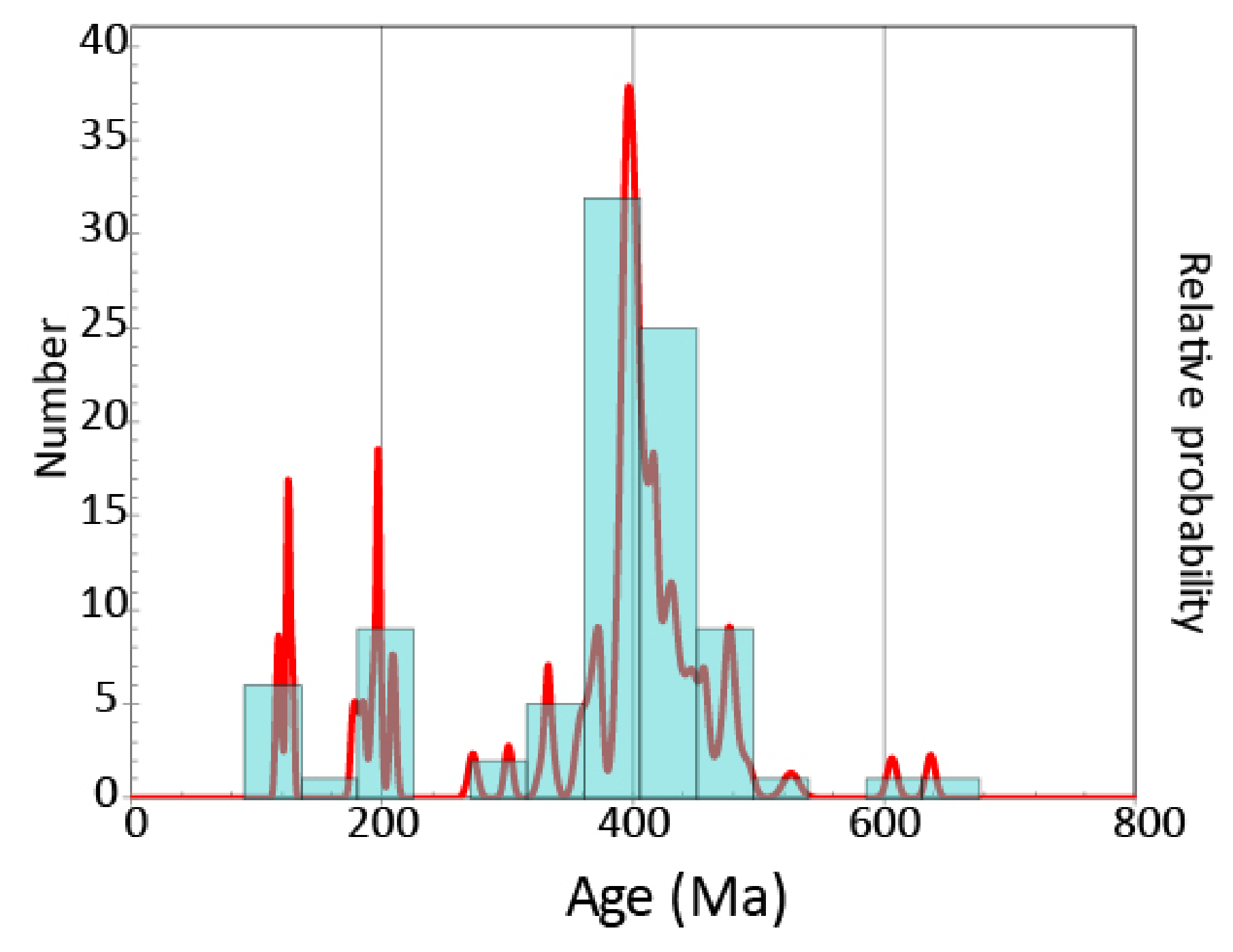


- Spike in $\mathrm{Gd} / \mathrm{Yb}$ at 400 $\mathrm{Ma}$ is consistent with melting in thickened crust

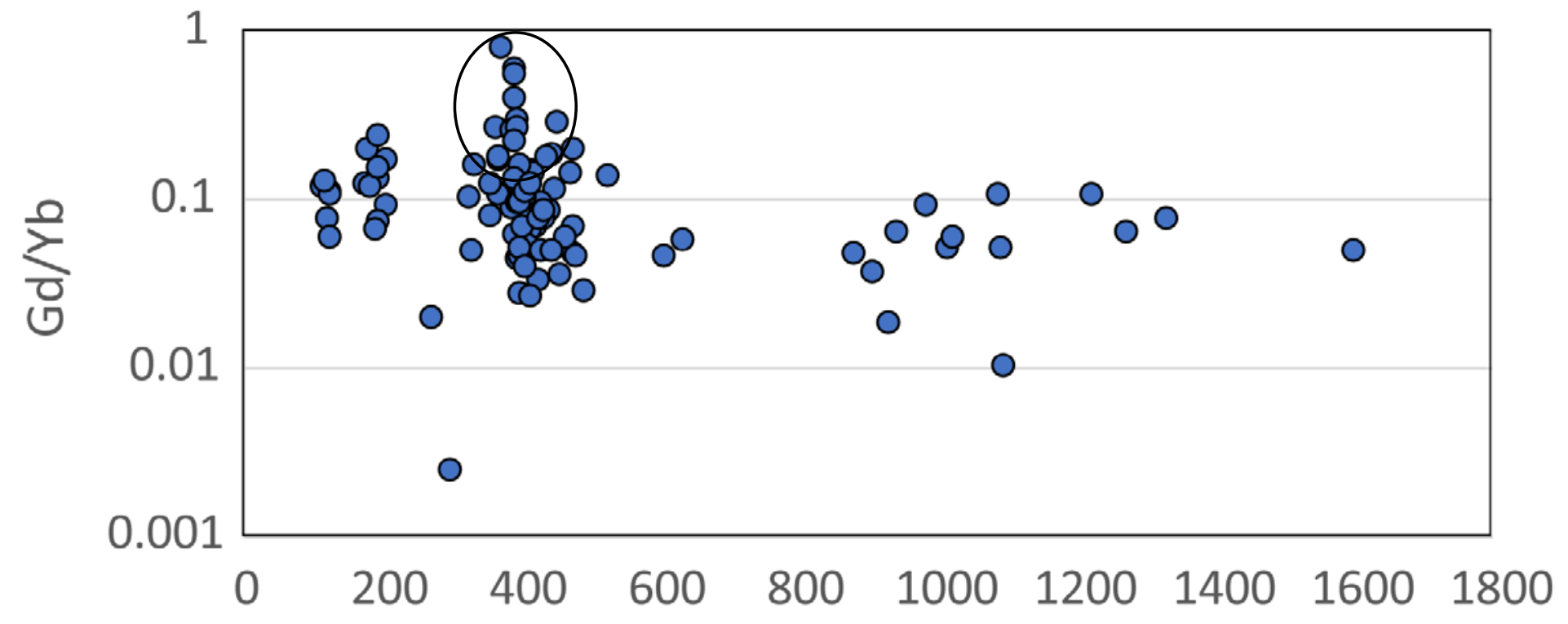

- Spike in Nb/Yb at 200 Ma consistent with alkalic A-type granites

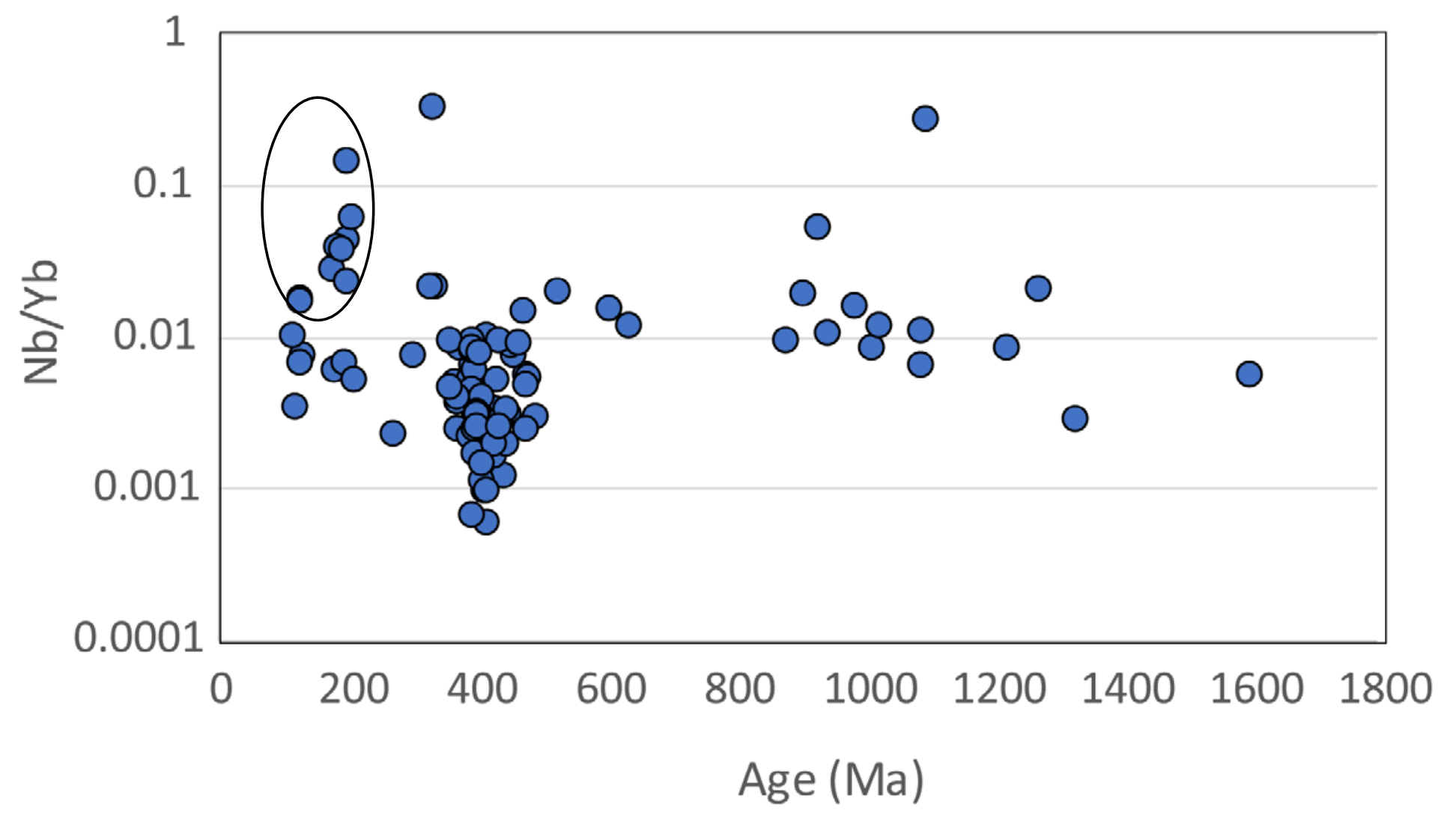




\section{Monazite age results}

- Peaks at 389, 277, and $347 \mathrm{Ma}$

- 389 Ma peak is slightly younger than main zircon age peak

- 277 Ma peak is absent from zircon age spectra

- No Precambrian ages

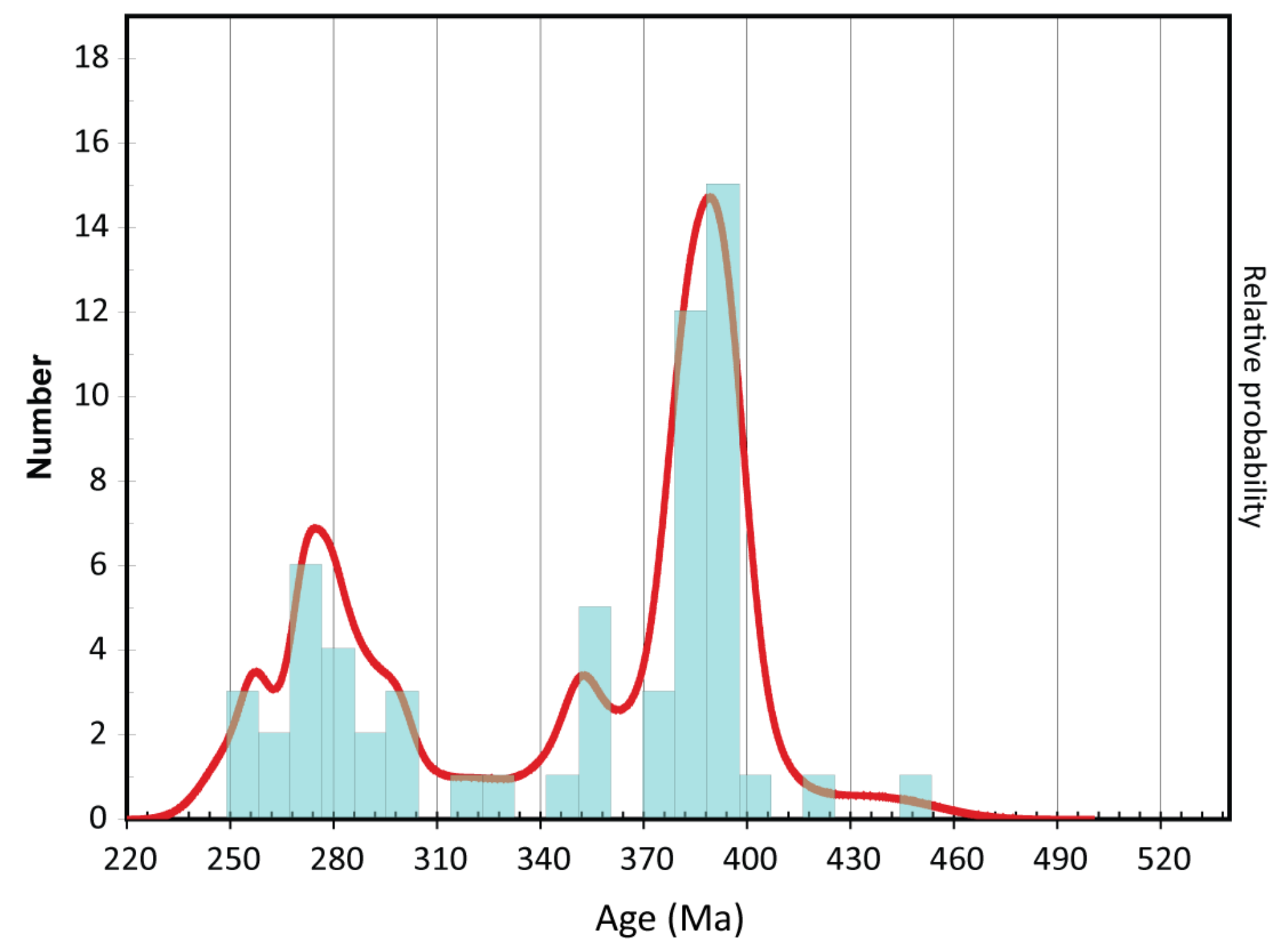


- Many of the oldest monazites grew in equilibrium with garnet and feldspar

- Itano et al. (2015) monazite discriminants would suggest that many of these are igneous monazites...

- But one would expect to see zircons of same age in detrital record if true
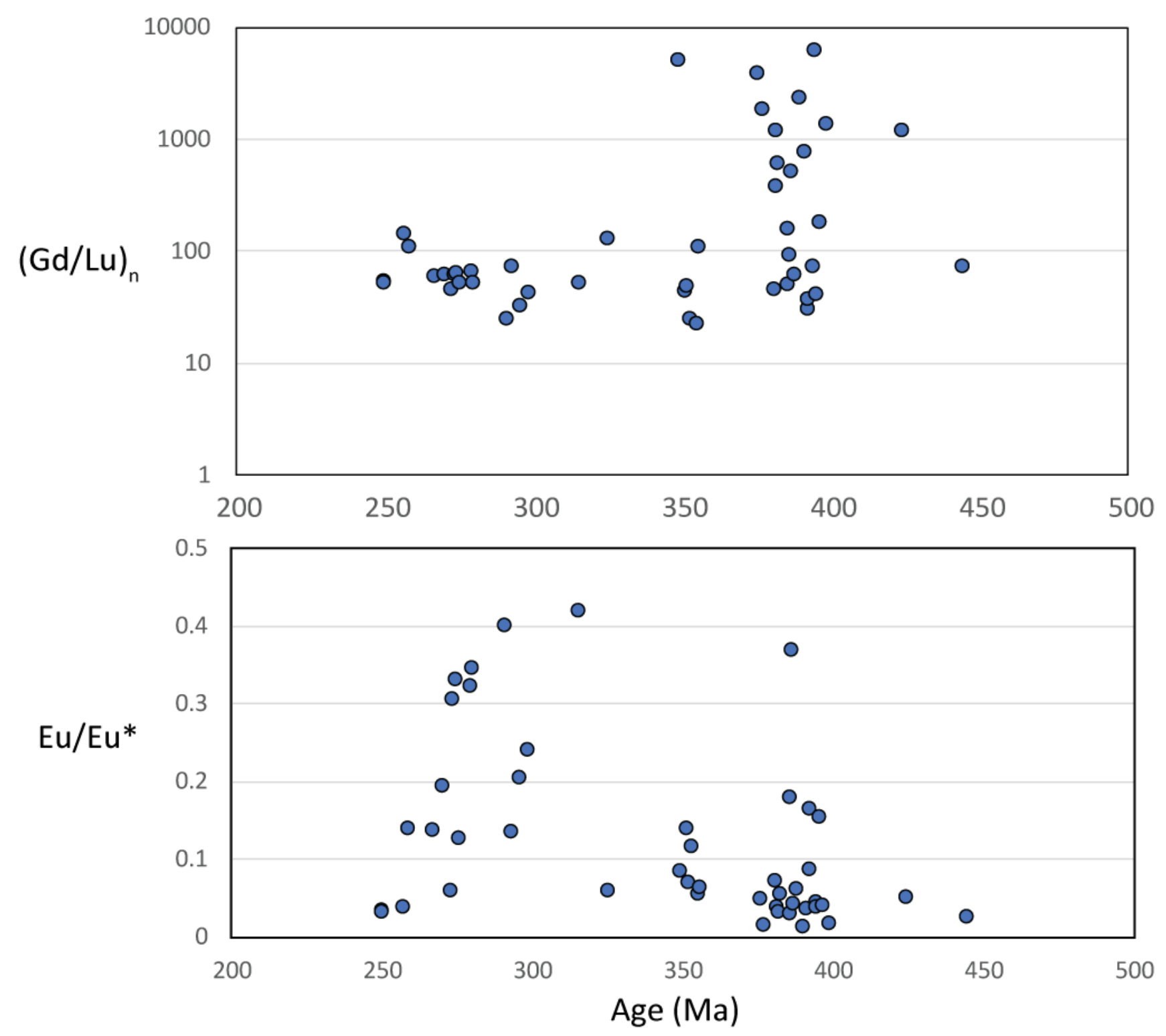
Rutile age results

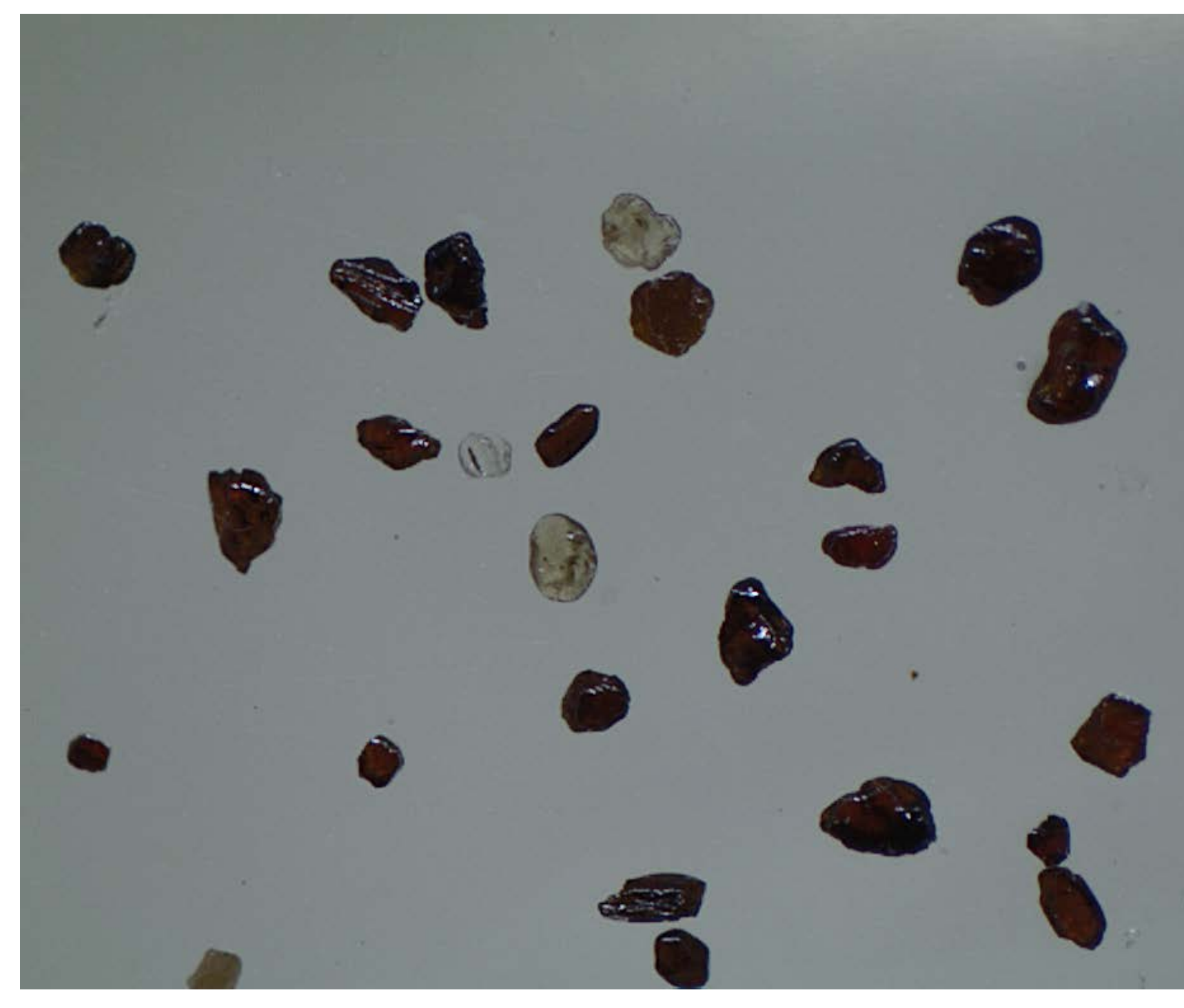




\section{Rutile age results}

- Hmm... Looks similar to monazite pattern

- Except each rutile peak is offset by 10 to 20 years

- This likely reflects the lower closure temperature of rutile $\left(\sim 500-550^{\circ}\right)$, indicating slow cooling/exhumation

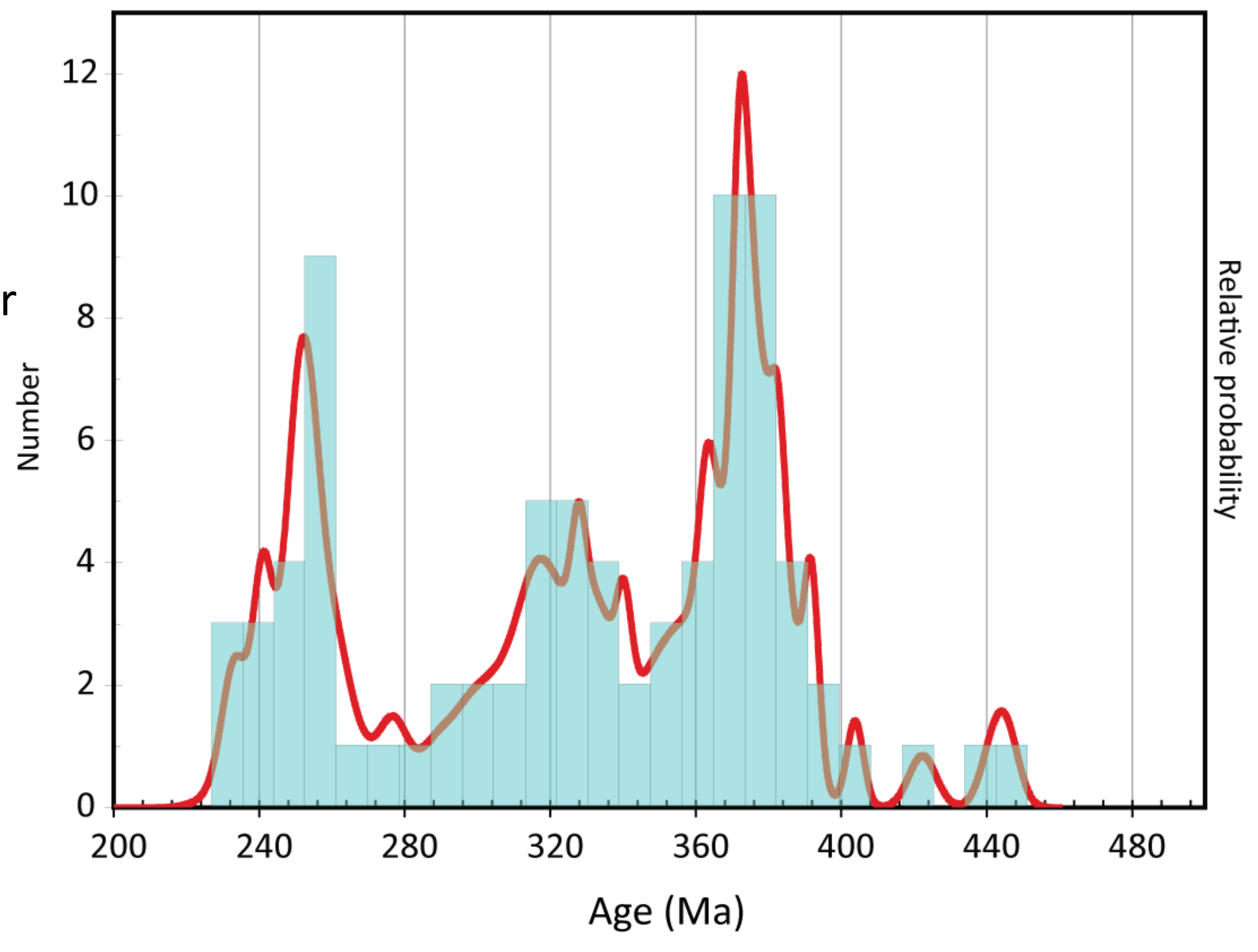




\section{Rutile age results}

- Hmm... Looks similar to monazite pattern

- Except each rutile peak is offset by 10 to 20 years

- This likely reflects the lower closure temperature of rutile $\left(\sim 500-550^{\circ}\right)$, indicating slow cooling/exhumation

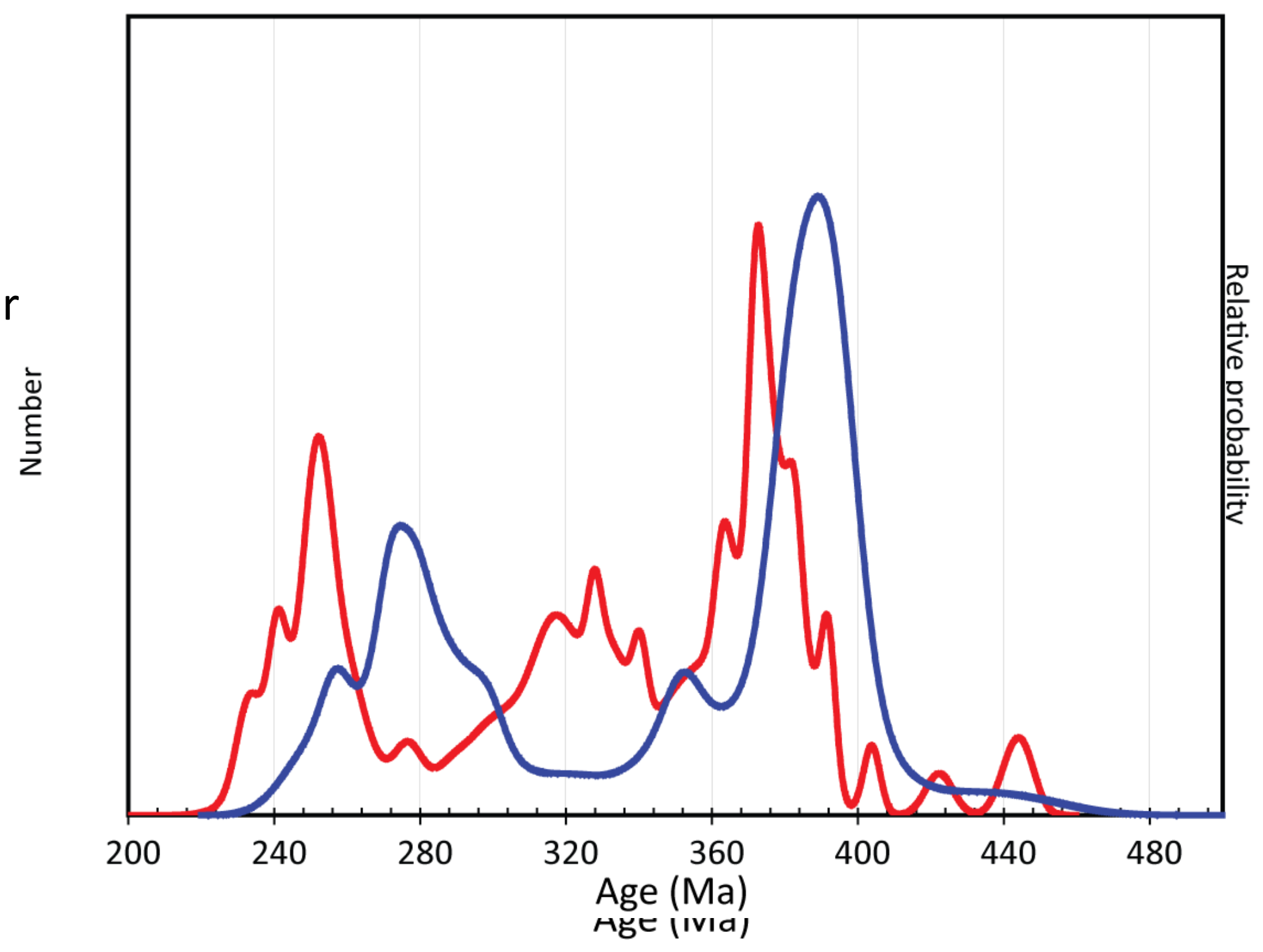


- $\mathrm{Cr}$ and $\mathrm{Nb}$ concentrations indicate mostly metasdimentary source rocks

- $\mathrm{Zr}$ thermometer indicates temperature in upper amphibolite to granulite conditions of growth

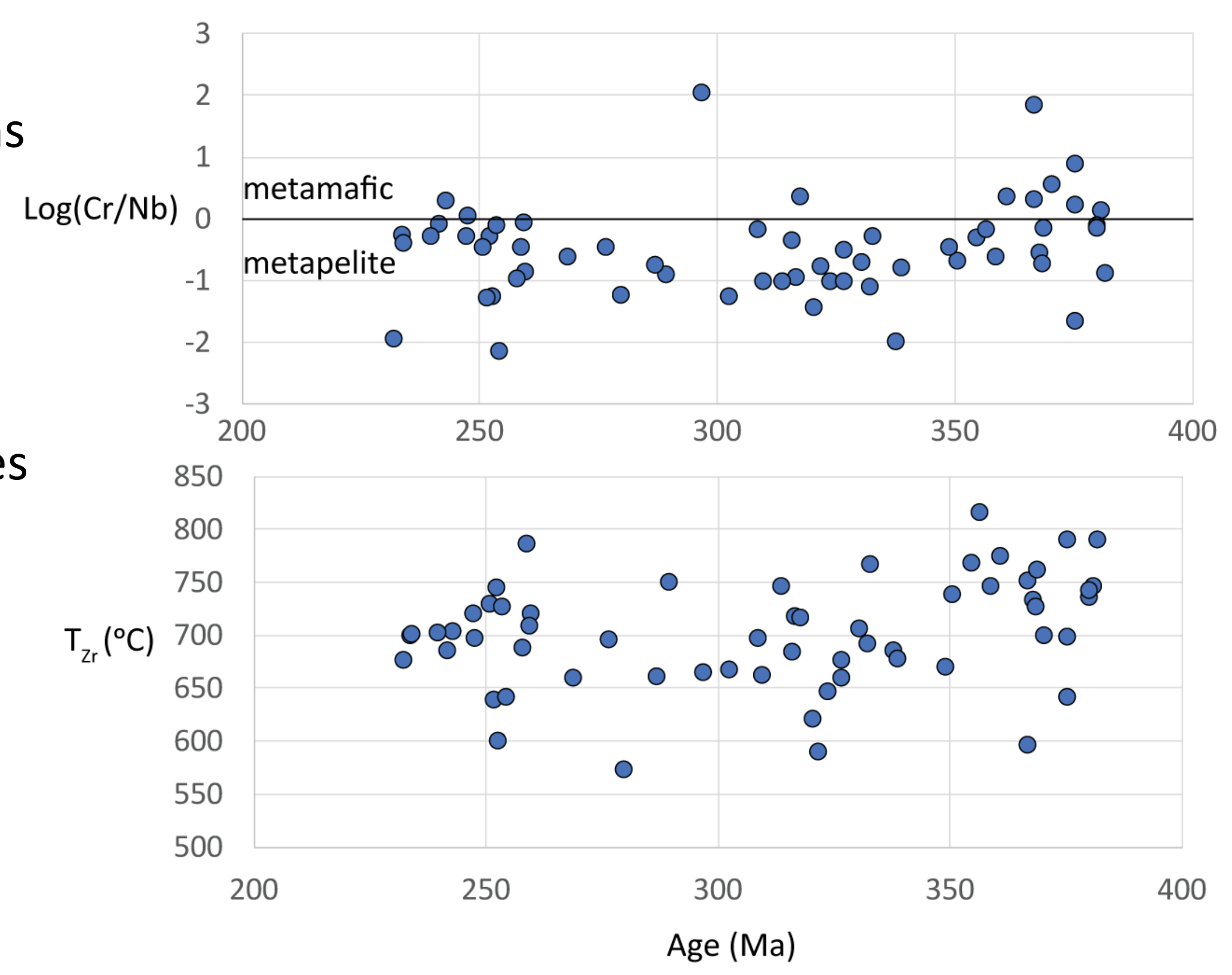




\section{A few titanites}

- Al and Fe content indicate magmatic origin

- Ages line up with minor zircon age peaks, reflecting more limited magma compositional range that crystallizes titanite

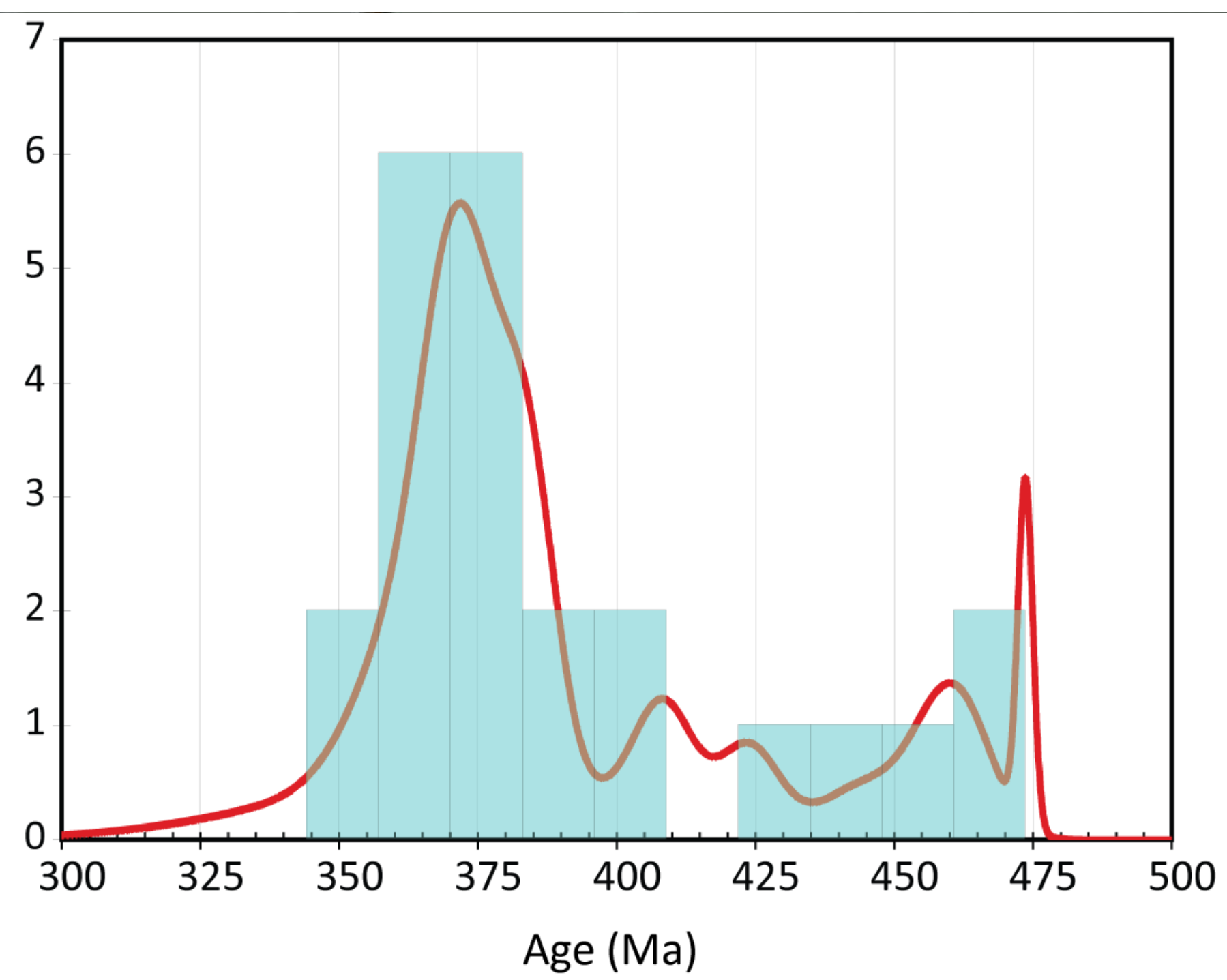




\section{Back to the alien geologists}

Minor Major

Zircon ages

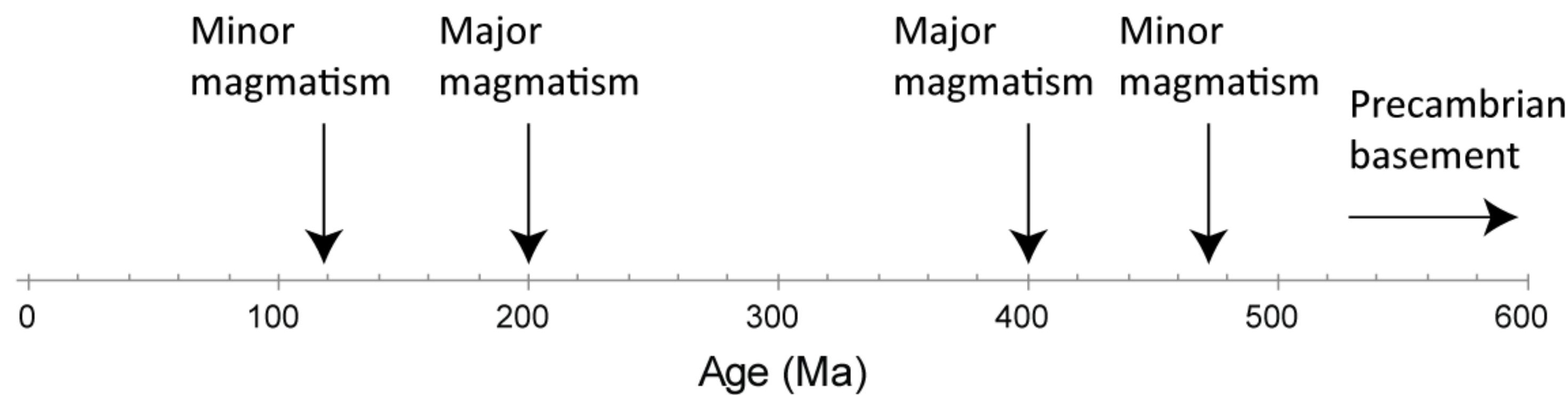




\section{Back to the alien geologists}

\section{Zircon TE}

Zircon ages

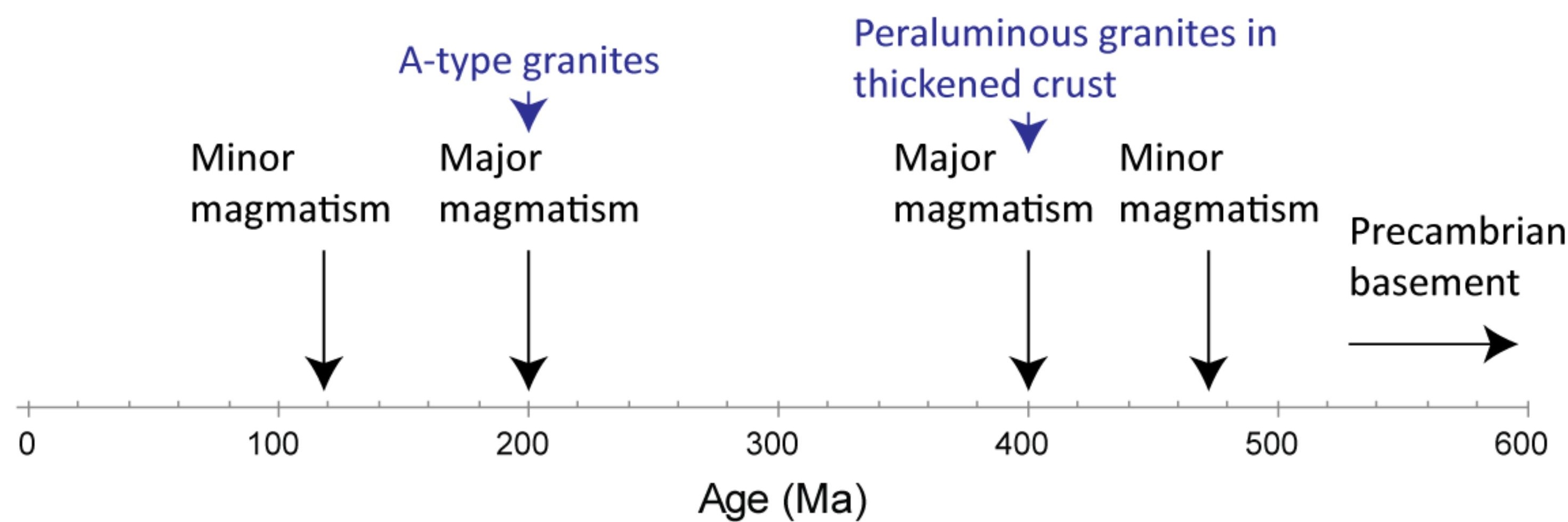




\section{Back to the alien geologists}

Monazite and rutile

\section{Zircon TE}

Zircon ages
Upper amphibolite metamorphism affecting metaseds

Minor magmatism magmatism
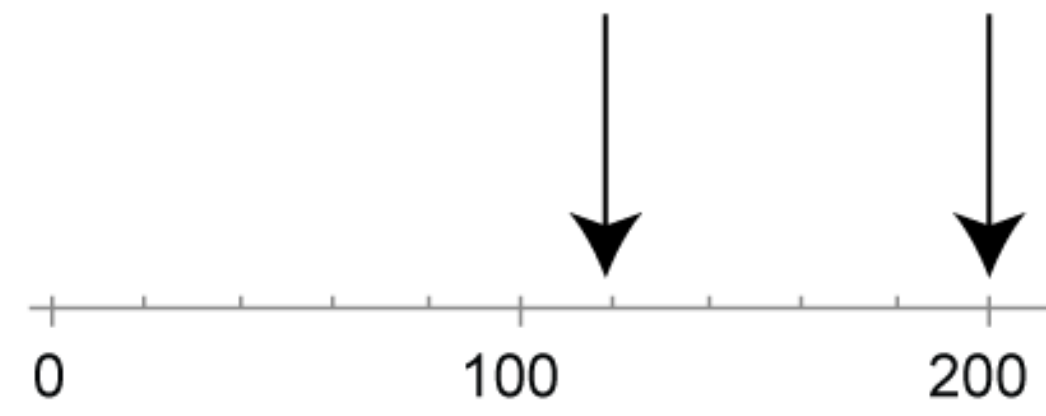

A-type granites

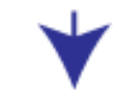

Major
Peraluminous granites in thickened crust

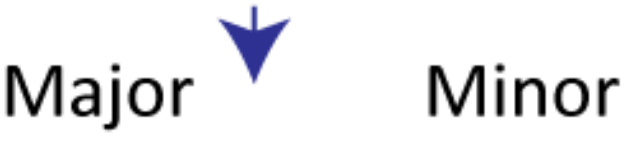

magmatism magmatism

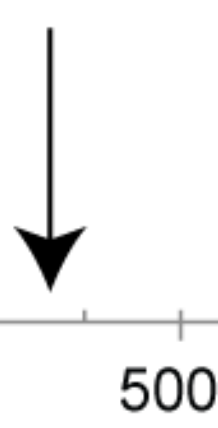

Precambrian basement

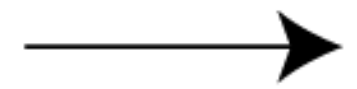

Age (Ma) 


\section{Back to the alien geologists}

Titanite

Monazite and rutile

\section{Zircon TE}

Zircon ages
Minor magmatism
Upper amphibolite metamorphism affecting metaseds

A-type granites

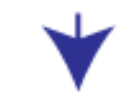

Major

magmatism

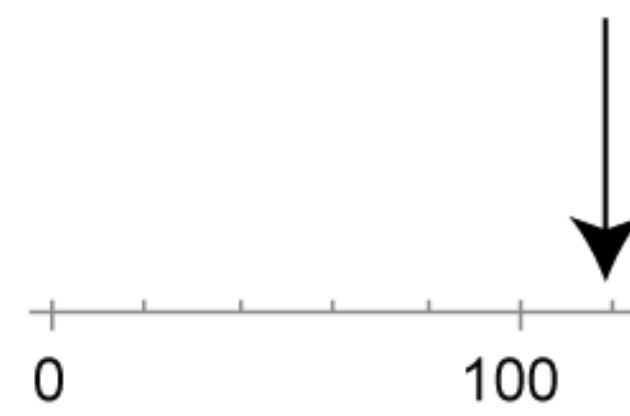

100

0

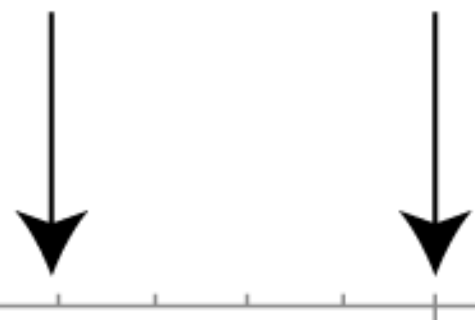

200
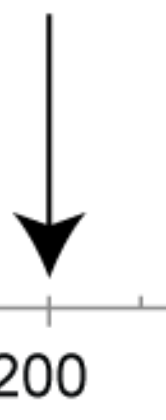

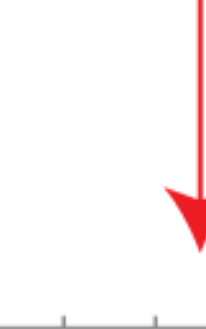

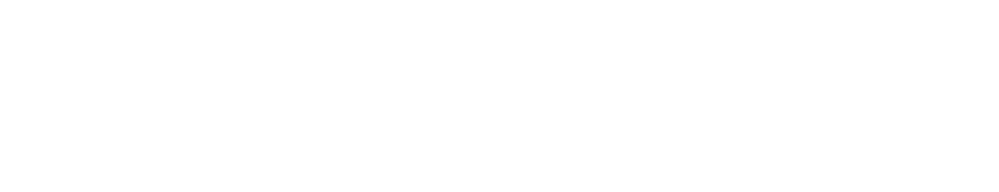

metaluminous

magmatism

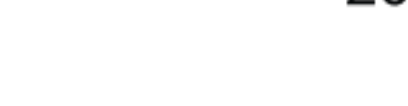




\section{Conclusions}

- Dating of detrital monazite, rutile, and titanite in conjunction provides crucial information on sedimentary provenance that is missed when dating only zircon

- In the case of the Merrimack River sands, multiproxy approach provides record of high-grade Alleghanian and later Acadian metamorphism that zircon dating alone misses

- Trace elements in zircon provide clues to tectonic settings of source rocks 